\title{
The Analysis and Regulation of Internet Finance Risk from the Perspective of Overall National Security
}

\author{
Bo Wang \\ School of Economics and Management \\ Weifang University \\ Weifang, China 261061
}

\begin{abstract}
As a new type of financial industry, internet finance has a lot of risk with the high rapid development, and it also has serious impacts on financial security. On April 25, 2017, the general secretary, Xi Jinping stressed that financial security was an important part of national security and an important basis for the steady and healthy development of the economy and put forward six specific tasks on the maintenance of financial security, which highlighted the need to focus on financial markets and Internet finance to carry out a comprehensive investigation. From the perspective of $\mathrm{Xi}$ Jinping's overall national security, this paper analyzes the internet finance risk from the four concepts: political security, economic security, social security and information security. And it also puts forward that it should obey the concept of Xi Jinping's overall national security as a guidance to build the the internet financial regulatory system for people's security, political security as the fundamental, economic security as the basis, social security for the protection.
\end{abstract}

Keywords-overall national security; Internet finance; risk; supervision

\section{INTRODUCTION}

On April 15, 2014, based on the complex situation at home and abroad and the new characteristics and the new trend of the changes of national security situation, the General Secretary, Xi Jinping viewed the situation and put forward the "overall national security concept" for the first time in the first meeting of the Central Committee on National Security. Xi Jinping asked to build a national security system integrating politics, land, military, economy, culture, society, science and technology, information, ecology, resources and nuclear security. In April, this year, the General Secretary, Xi Jinping pointed out that the financial security was an important part of national security and an important foundation for the steady and healthy development of the economy in the 40th Collective Study of the Political Bureau of the CPC Central Committee. Safeguarding financial security is a strategic, fundamental event relating to the development of China's overall economy and society. Internet finance, as a new area of financial, its risk has been fully exposed after a few years of brutal growth. It is currently in the stage of consolidation, reshuffle, and the redevelopment. Its industry competitiveness, anti-risk ability and sustainable development capacity are important parts to hold systemic financial risk. The author believes that the internet finance should be supervised in the perspective of overall national security. And it should be fully aware of its status and role in financial industry and economic development and social life. And it should continue to strengthen supervision, so that the internet finance could become both "strong of the engine" and "wear-resistant brake pads".

\section{INTERNET FINANCE RELATING TO THE NATIONAL SECURITY}

Recalling the development of China's Internet finance so far, it just uses a few dozen years to go through the development of the traditional industry which needs decades years. In this stage from 2006 to 2011, it is a breeding period, and the market is full of doubt, hesitation, encouragement, learning, opposition, indifference and other reactions. From 2012 to 2015 , the growth period, as the representative of the Internet financial industry, P2P has got brutal growth, and then the risk has been exposed. From July, 2015, with the internet finance entering a comprehensive rectification period, the regulations became the main theme, and some institutions began to quit. With the absence of pre-regulatory oversight, lacking of rules, the Internet's brutal growth is inevitable, and the market participants have to go through a gradual process of maturity. In April, 2016, the relevant departments of the government carry out a one-year Internet financial special rectification action which organized by the State Council. And this activity has ended. The state is sure of internet finance's innovation, and standardizes the basic attitude of development. According to the comprehensive information, the government maintains the high degree of emphasis on the maintenance of internet financial security. Xi Jinping, the general secretary also requires to focusing on the Internet to conduct a comprehensive financial planning and investigation.

With the position of the finance and Internet finance risk and lacking of supervision, the central government pays attention to the Internet so much. The general secretary, Xi Jinping points out that finance is the core of modern economy. It should make finance alive and stability, economy flexible and stability. Since the reform and opening up, it has been more than 30 years. The reform and opening up and development of finance have a strong influence to optimize the allocation of resources, coordination of interests and promote the role of economic 
and social development. As an important subsystem of economic security, financial security runs through all aspects of "overall security" and is a strong support for safeguarding national economic security and has effectively maintained and promoted the overall security of the country. Internet finance, as a new type of financial industry, is the integration of Internet genes and financial genes. They are based on the traditional financial coupling of Internet technology and information and communication technology. It is the innovation of traditional financial services. This financial innovation breaks the time and space constraints of traditional financial services, optimizes the allocation of financial resources, improves the efficiency of financial services, reduces the cost of financial transactions, and enhances the financial consumption experience. And it also has significant characteristics of generalized preferences, convenience, openness and sharing. But the nature of Internet financial is still finance, and its financial functions and the nature has not fundamentally changed. It just embedded in the Internet technology in a wider range of financial applications, better achieved the financial services of the generalization, the convenience, open and decentralized. Its future innovation and competition still depends on the effective identification of market risks and product pricing and management capabilities.

In recent years, with the influence of factors such as international and domestic economic downturn and the background of macro policy such as "three to one drop" and so on, all kinds of Internet finance enterprises have taken pressure and fraud Internet risk in the rapid innovation. And it takes out huge risk in the development of the internet finance, and these risks superimposed the characteristics of concealment, agglomeration, vulnerability and infection on the basis of traditional financial risk in Internet industry, resulting the risk factors into a geometric multiple magnification. Internet financial risk is not only related to the security and stability of financial markets, but also affects the basis of national security - economic security and then affects the overall national security. Based on the trend of Internet finance and the characteristics of risk, the current risk of Internet finance has attracted more and more attention from financial regulators and even the governments, and it also puts forward new challenges and requirements for the current supervision model of Internet finance. Since April, 2016, with the special rectification action carried out, regulatory policy gradually landed; industry governance continued to deepen; it ended the brutal growth of Internet finance industry. The overall environment and the level of risk tend to be improved, but the industry itself is still in high risk. "Internet Finance" has been written into the government work report for four consecutive years. The relevant expression has been changed from "to promote healthy development" into "standard development", and further into a "high degree of vigilance accumulated risk". The regulate governance of Internet financial industry is still the most important risk prevention in this year.

\section{THE ROLE OF INTERNET FINANCE IN MAINTAINING OVERALL NATIONAL SECURITY}

Internet finance, as a new type of financial industry, can play a positive role in optimizing the allocation of resources, improving financial efficiency and safeguarding the overall national security. With the reform and opening up developing into the "deep water", more unforeseeable risks appear. The Internet finance has advantages in the supply of funds, efficient supply, information supply and other aspects. And with the healthy development of the industry at the same time, it also has great potential externalities for safeguarding national security. It is mainly in the following areas:

The financing system of Internet financial diversification provides financial support for the maintenance of national security. The diversified financing system of Internet finance can provide sustained and stable financial support for the development of military industry, cultural industry, high-tech industry and eco-environmental protection industry in a country, and help to strengthen the military hard power, cultural soft power, new technology and sustainable development capacity and so on. Especially in recent years, with the rapid development of Internet finance, relying on the Internet platform in a more efficient way, more diversified model to a wider range of fund holders initiating financing activities gradually raise. At present, many cultural industries, high-tech innovation industries have begun to try this financing way. The financing models can be extended to the military industry, eco-environmental protection industry and other more national security-related industries for the construction of national security system to provide strong funds to support footnotes in the future.

Internet finance, as a financial innovation, enhances the efficiency of the national security system. Internet finance is the financial technology innovation under the guidance of modern information technology, diversified financial product innovation and financial service innovation. And it is based on the changes of industry development concept. And it is coupled with Internet technology and financial business, cross-border relevance and the optimized resources. The efficiency of the allocation of financial capital has accelerated the flow of financial capital in different industries and improved the efficiency of financial services operation. It is an important way to ensure the efficient operation of national subsystems.

Internet finance provides important information to maintain national security based on large data, cloud computing and other technologies. For instance, the establishment of Internet financial accounts, changes and other relevant information provide monitoring objects for the national security system. Internet financial accounts' abnormal flow of funds provides early warning signals for national security. According to the digging, the integration, the analysis and application of the Internet financial institutions internal system data, external public data and Internet social Media behavior data, it can scientifically determine the internal financial risks and external environmental changes and provide critical information for 
anti-money laundering, anti-fraud and other warning clues to prevent security risks to support for the protection of the country security system. And it plays an important role.

\section{THE ANALYSIS OF INTERNET FINANCE RISK FROM THE PERSPECTIVE OF OVERALL NATIONAL SECURITY}

The concept of overall national security, as a guidance to maintain and shape the security with Chinese characteristics, has important practical significance in preventing and defusing economic and financial risks and consolidating the economic security foundation. From the analysis of the overall national security, the Internet finance has at least directly related to political security, economic security, social security, information security and so on, and it also have an impact on other aspects of national security based on the above analysis indirectly. The general secretary, Xi Jinping stressed that accurate risk assessment was a prerequisite to protect financial security. Overall, China's financial situation is good, and financial risk is controllable. At the same time, Internet finance, as a high risk of new financial formats, the time to prevent and resolve the risk is urgent, and the task is heavy. The identification of the root cause and the accurate judgment has become the way to reverse the development of this industry. In the perspective of overall national security, the dimension of Internet financial risk:

\section{A. Political Security}

Internet financial enterprise has low barriers for market. In fact, lacking of pre-regulation and supervision, the industry is full of traditional financial services such as "private lending networks" and so on, which are not financial innovation. Actually, these things are regulatory arbitrage, and there are many Ponzi scheme in this process. Due to the characteristics of Internet financial products and services, such as delicacy and network externalities, in case of risk, the Internet finance would have wider, deeper impacts through the chain of risk in the inherent and extensive dissemination of the Internet. And the financial institutions and regulators are difficult to control the situation in a short time. This can easily lead to a range of social unrest and political instability. At the same time, the Internet financial industry is quite mixed. The platform does not carry out the transaction legitimacy audit, and some of them even take the initiative to help enterprises use false trade background, illegal payment settlement, overseas security and other services for money laundering, to provide access for hot money outside. Nor does it preclude the possibility that Internet financial firms will provide funds to organizations and even hostile forces overseas. This chaos of industry has seriously affected the country's political security.

\section{B. Economic Security}

In the process of Internet financial development, due to lack of supervision, the shadow banking and other issues are more prominent. It is easy to lead to systemic risk. Moody's data shows that China's shadow banking system grew by $19 \%$ to 58 trillion yuan in the first half of 2016, and it's about $80 \%$ of China's economy. The proportion of Internet finance is higher and higher. There is a huge risk behind the scale of expansion. Let's take P2P as an example. First, P2P companies are out of their own position. The specific performance of the domestic P2P companies is mostly far from the role of pure information. Most of them would build pool of funds, provide credit guarantee and so on. And some of them even play investors, banks, security companies and other multiple roles at the same time. It greatly increases liquidity risk and credit risk. Second, some P2P companies use the form of transferring debt to make business. P2P companies firstly lend the loans to the borrower to obtain the corresponding claims, and then large, long-term claims are divided into small, short-term claims or financial products scattered to investors. Usually, in order to ensure the funds in place, it would sale products in a few months ahead of time to raise funds. Due to mismatch maturity, capital misappropriation risk is difficult to avoid. And it easily leads to liquidity risk, seriously affects the stability of financial market. Third, the high interest rates and high leverage of Internet finance is not benefit for finance to support the real economic development and the implementation of the "three to one down one" policy. Some Internet financial products attract investors through the high rate of returns accompanied by high leverage rate. High leverage mode of operation will cause the Internet financial business risk is too high. If the control capacity is insufficient, the entire capital chain will break once the large amount of borrowing overdue the time. From the asset side, these funds are invested by a lot of "two high and one left" industry, real estate projects and even zombie enterprises. It would have serious squeeze effects on the real entities economy and the shortages of funds, which run in opposite direction for the focus of China's current economic work.

\section{Social Security}

Most of the funding providers of Internet finance are individual customers who are lack of professional financial background. Usually, their risk tolerance is low with lacking of financial market risk and management ability. And they belong to risk aversion. Most of the demands for funds are the persons that who is lack of collateral, or credit rating is low or small and medium enterprises and individuals are lack of credit information. The enterprises and individuals usually contain a greater risk. The explosive growth of Internet finance is precisely due to serve such a large number of customer groups which traditional finance is difficult to effectively cover. However, the financial knowledge reserves and risk identification and afford-ability of the financial consumer groups are inadequate. It is difficult to fully understand the Internet financial revenue and cost asymmetry. And the Internet financial enterprises are both lack of the assessment and afford-ability of the fund supplier's risk, and lack of effective risk identification, evaluation and pricing for the demand side. In addition, some Internet financial enterprises have illegal business, or provide credit guarantee, or make illegal pool of funds, and even criminals use information, knowledge and other asymmetric implementation to do the network illegal fundraising, financial fraud and other criminal activities. Some large cases spread in a wide range, which are involving a large number of large amounts. The funds were squandered, and the serious waste is difficulty to recover. With some 
policy advocacy and case announcement is not thorough, it is easy to induce social mass incidents and social security.

\section{Information Security}

The development of Internet finance has benefited from the popularization of computer and the breakthrough of modern network information technology, which also brings a series of problems such as technical loopholes, network security and information leakage. According to data released by China Internet Information Center, there are 2.47 million computers and 1.08 million units Andrews smart phone infected with the Trojan horse and other malicious programs in the end of 2016, resulting in frequent network security incidents. Worthier to note is that $80 \%$ of the high-end chips, $90 \%$ of the underlying software depend on imports in China. And $80 \%$ of the general agreement and standards are adopted abroad. Once these imported hardware and software are left "leak", its potential threat to financial information security is difficult to identify and it can't eradicate. At the same time, the Internet financial industry is highly dependent on personal information, but the current credit system is not perfect. The Internet financial platform is lack of effective channels to verify customer information. Some ways to confirm is more primitive, and some ways have to confirm face to face. It is not convenient to play the advantages of efficiency. With the development of large data, the development and application of cloud computing, the way to confirm information has widened. Because the Internet financial data depends on large, cloud computing, information security has become a new challenge. And improper operating procedures and internal control, illegal intrusion and information disclosure will have a serious impact on information security and Internet financial service system. Especially in recent years, with the Internet penetrating in all ways of life, the Internet information security risk events and the cases which sales customer information for profit are common. Previously, in the development of the Internet financial industry, the "wind control" focused on both sides' financial security. They are less concerned about the information security in exchanging data issues. With a large number of customer information and financial information stored in the Internet platform, it only relies on the single technical support. There are a high moral hazard and security risks.

\section{REgUlatory PROPOSALS FOR INTERNET FINANCE} FROM THE PERSPECTIVE OF OVERALL NATIONAL SECURITY

Finance is closely related with national security. The general secretary, $\mathrm{Xi}$ Jinping pointed out that the maintenance of financial security must adhere to the bottom line of ideology, adhere to the problem-oriented. On the basis of comprehensive financial work, it should focus on deepening financial reform, strengthening financial supervision, scientifically guarding against risks and strengthening safety and capacity building. The countermeasures of Internet financial risk and security regulatory task are very arduous. In the practice of Internet financial supervision, we should build the Internet security for the people, political security as the fundamental, economic security as the basis, social security for the protection of the Internet financial regulatory system based on the concept of overall national security.

\section{A. For the Purpose of People' Security}

First, it should establish the Internet Financial Investor Protection Fund. And it is prepared for the Internet financial business bankruptcy or accidental runway. And then the investors can get a certain degree of repayment through the fund in accordance with relevant policies to protect the safety of founds. In the end, it could be the long - term mechanism to prevent and dispose Internet business risk. Second, the government should introduce personal information protection laws and other relevant laws and regulations to protect the Internet financial transactions parties to the personal information security and financial information security, develop the appropriate management systems and processes, use encrypted storage and encryption means to protect personal information and important data from leaking important Information, enhance information security and maintain the network security.

\section{B. To Take Political Security as the Foundation}

The first thing is to improve the threshold of Internet financial industry, standardize the Internet financial platform for the registration, increase the supervision of the Internet financial platform transaction legitimacy, closely monitor the capital flows of Internet financial platform, improve the vigilance of money laundering, hot money overseas and foreign forces provided by the internet finance platform, improve the relevant plans and regulatory requirements. Second, National and local financial supervision, public security, security, auditing and other departments take efforts to maintain real-time information exchange, resource sharing, collaborative linkage, common fight against the national political security of the Internet financial chaos.

\section{To Take Economic Security as the Basis}

First, it is clear that the Internet finance should be in the national macro-control, obey the objective requirements of the service economy, guide the industry to broaden the financing channels, strengthen the credit policy guidelines, and promote the supply side of the structural reform. Second, it should pay attention to building a multi-level financial market system. And it guides the advantages of complementary institutions, collaboration, avoids homogeneous competition. It is good to define the boundaries of business, clear the main body's supervision, innovate regulatory ideas. Due to the different Internet financial operators and the mixed operation, it can try to guide the classification, industry self-discipline, administrative supervision of the joint management ideas. Third, it must grasp the appropriate regulatory standards, take both "efficiency" and "security" issues, and achieve balance in the dynamic game of innovation and regulation. It should ensure that the overall risk is in control, financial market and economic operation is stability. Under the premise of that, it should encourage financial innovation, release the vitality and efficiency of the Internet finance. And it is better to serve the real economy. 


\section{For Protecting the Social Security}

Firstly, it should make the innovation of the credit information system and develop the appropriate private credit system to promote its coordination with the credit system which is leaded by the government. And it also can effectively reduce credit risk of the Internet financial industry. Secondly, it should put the focus on the Internet financial platform with those "three more" such as more funds, more customers, and more negative news. It also should strengthen cooperation with the relevant departments to establish the Internet financial company data reporting system and use large data technology, monitor closely the object business flow, information flow, capital flow, pay attention to the assessment and early warning of the mentality, the tendency. And then it can make the effective management of Internet financial innovation, and firmly hold the bottom line to prevent the systemic financial risks. Thirdly, it should strike the illegal use of Internet money under the name of illegal fund-raising, financial fraud and other criminal activities. And some cases which spreading a wide range, involving a large number of large amounts and serious social repercussions should be disclosed in a time. Fourthly, it should increase the investment in the Internet financial management knowledge, risk education, develop their risk awareness, and improve their ability to identify risks, control risks. At the same time, it also can strengthen the leadership of the financial work capacity of the training, urge them to learn financial knowledge and be familiar with the financial business, to grasp the laws of finance, strengthen supervision awareness and improve the efficiency of supervision.

\section{CONCLUSION}

Financial security, as an important weapon to achieve the overall national security, has a pivotal position in the overall national security system. Internet finance, as a new form of finance, belongs to a high-risk area in the financial sector, which affects the security and stability of the economy and the overall security of the country. It is reported that Internet financial risk special rectification work scheduled to be completed in March, 2016. However, it will be delayed for about a year. Under the current situation, it should adhere to the concept of national security as a guide in the process of regulating the Internet finance. It should build the Internet Financial regulatory system for the people's security, political security, economic security, social security to promote the healthy development of the Internet finance to make it better serve the real entities.

\section{REFERENCES}

[1] Song Xiaowei, Huang Yuncheng. Risk Prevention of Internet Finance [J]. China Finance, 2017 (4)

[2] Yuan Hui. Watch out for the five major risks of Internet finance [N]. Study Times, March 17, 2017

[3] Zhang Chenghui. China 's Internet banking regulation and development [J]. Financial Forum, 2016 (10)

[4] Zhang Hongli. Finance and national security [J]. China Finance, 2015 (10) 